\title{
Management of Plant-Parasitic Nematodes in Florida Peanut Production'
}

\author{
Zane J. Grabau and Donald W. Dickson²
}

\section{Nematodes in Peanut Production}

Nematodes are non-segmented roundworms that are generally microscopic. They live in animal hosts, soil, plant roots, or water. Nematodes in agricultural systems usually live in soil and can be divided into three categories: (1) entomopathogenic nematodes that feed on insects; (2) free-living nematodes that feed on bacteria, fungi, or other nematodes and may be beneficial for crop production; and (3) plant-parasitic nematodes that feed only on plants and may drastically suppress yields on many crops, including peanut.

Some of the more virulent plant-parasitic nematodes of peanut reduce yield by decreasing root size and efficiency, leading to shorter shoots. Infected plants are generally stunted with varying degrees of yellowing (chlorosis). They produce fewer pegs and pods, and, in severe cases, die. Severe nematode infection, sometimes in combination with secondary infection by fungal pathogens, may also rot pods. The amount of damage nematodes cause is related to their population densities; the higher their density, the greater the damage.

Nematode population densities can increase rapidly in the field. Most plant-parasitic nematodes of peanut complete their life cycle (egg, four pre-adult juvenile stages, egg-producing adult) in three to four weeks depending on the nematode species and environmental conditions. On peanut, which is an approximately 135 -day crop, nematodes may go through six or more generations in a single growing season. A mature female nematode can produce upwards of several hundred eggs, depending on the species of nematode and environmental conditions.

Plant-parasitic nematodes of peanut spend their entire lives in soil or roots and can be sorted by where they reside when feeding, a fact that is important to remember when sampling for nematodes. Ectoparasites (ecto means outside) spend their entire lives outside the roots. Only the head end or stylet of an ectoparasite enters the roots when feeding (Figure 1). (A stylet is a needle-like mouthpart that all plant-parasitic nematodes possess.) Endoparasites (endo means inside) enter the root as a juvenile or adult and remain in the root to feed. Some endoparasites are migratory, which means they move while feeding. Other nematodes are sedentary, which means that they do not move once they begin feeding. A portion of the population of endoparasitic nematodes can be found in the soil at any given time because eggs generally hatch in the soil and mobile nematode stages may move freely in soil or from root to root.

1. This document is ENY069, one of a series of the Department of Entomology and Nematology, UF/IFAS Extension. Original publication date February 2018. Visit the EDIS website at http://edis.ifas.ufl.edu.

2. Zane J. Grabau, assistant professor; and Donald W. Dickson, professor, Department of Entomology and Nematology; UF/IFAS Extension, Gainesville, FL 32611.

The use of trade names in this publication is solely for the purpose of providing specific information. UF/IFAS does not guarantee or warranty the products named, and references to them in this publication do not signify our approval to the exclusion of other products of suitable composition. Use pesticides safely. Read and follow directions on the manufacturer's label.

The Institute of Food and Agricultural Sciences (IFAS) is an Equal Opportunity Institution authorized to provide research, educational information and other services

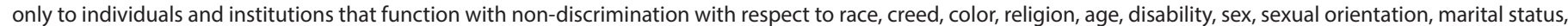

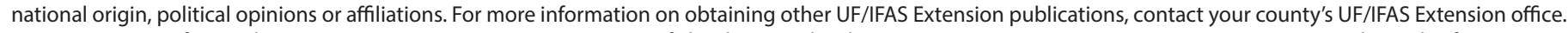
U.S. Department of Agriculture, UF/IFAS Extension Service, University of Florida, IFAS, Florida A \& M University Cooperative Extension Program, and Boards of County Commissioners Cooperating. Nick T. Place, dean for UF/IFAS Extension. 


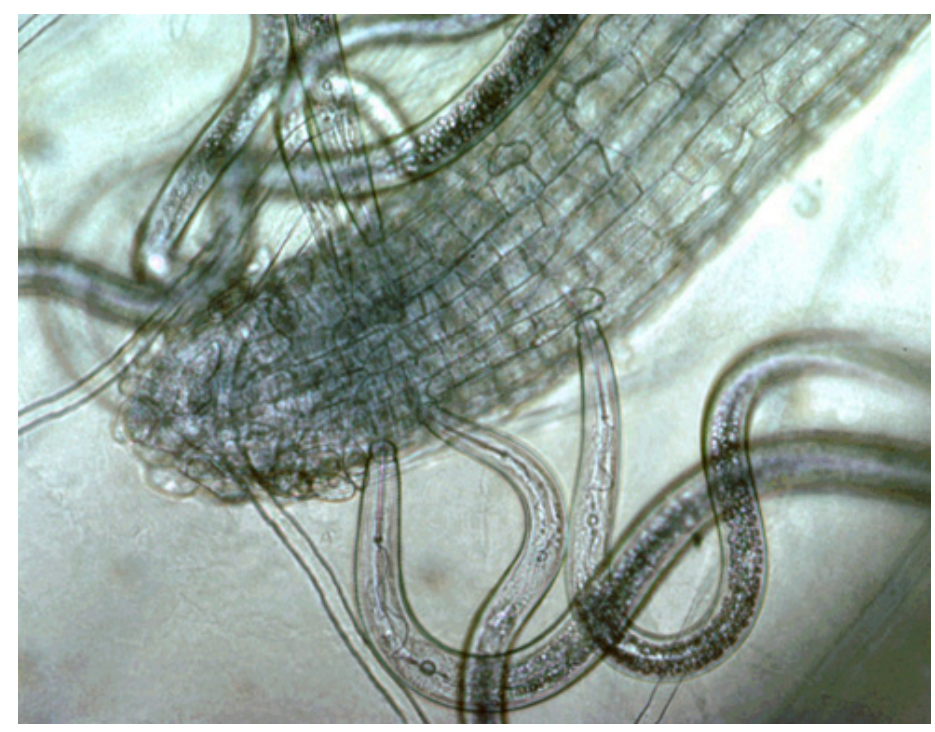

Figure 1. An ectoparasitic nematode (sting nematode) feeding from outside roots.

Credits: Ole Becker, University of California, Riverside; used by permission

Among plant-parasitic nematodes in Florida, root-knot nematodes (Figures 2 and 3), which are sedentary endoparasites, cause the most yield suppression to peanut because they are common and have high damage potential. Peanut root-knot nematode (Meloidogyne arenaria) and Javanese root-knot nematode (Meloidogyne javanica) both damage peanut in Florida, although the former is more common. There are many species or types of root-knot nematodes, and it is important to distinguish between these types because the different types infect different crops.

Some species are also divided into different races based on the hosts they infect; however they are visually similar if not identical. For example, race 1 of the peanut root-knot nematode infects peanut, but race 2 does not; races 3 and 4 of the Javanese root-knot nematode infect peanut, but races 1 and 2 do not.

Lesion nematode (Pratylenchus brachyurus, Figure 4), a migratory endoparasite, is widespread, but is only moderately damaging. Peanut ring nematode (Mesocrionema ornatum), an ectoparasite, commonly infects peanut but has low damage potential. Sting nematode (Belonolaimus longicaudatus, Figure 5), an ectoparasite, occasionally causes serious damage to peanut. Sting nematode is probably not widespread in peanut production regions because it only occurs in sandy soils ( $80 \%$ or greater sand, $10 \%$ or less clay) with minimal organic matter. Root-knot and lesion nematodes that affect peanut can infest a wide range of soil types, although they tend to thrive in sandier soils. See the UF/IFAS publication on sting nematode for more information about this nematode.

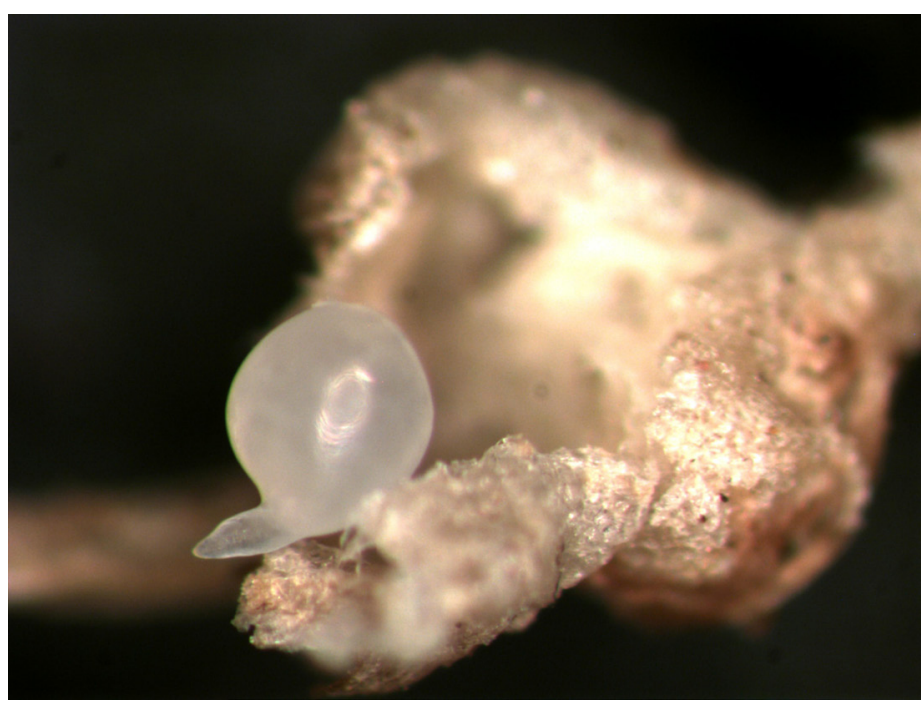

Figure 2. Mature female root-knot nematode removed from root. Credits: Charles Overstreet, Louisiana State University; used by permission

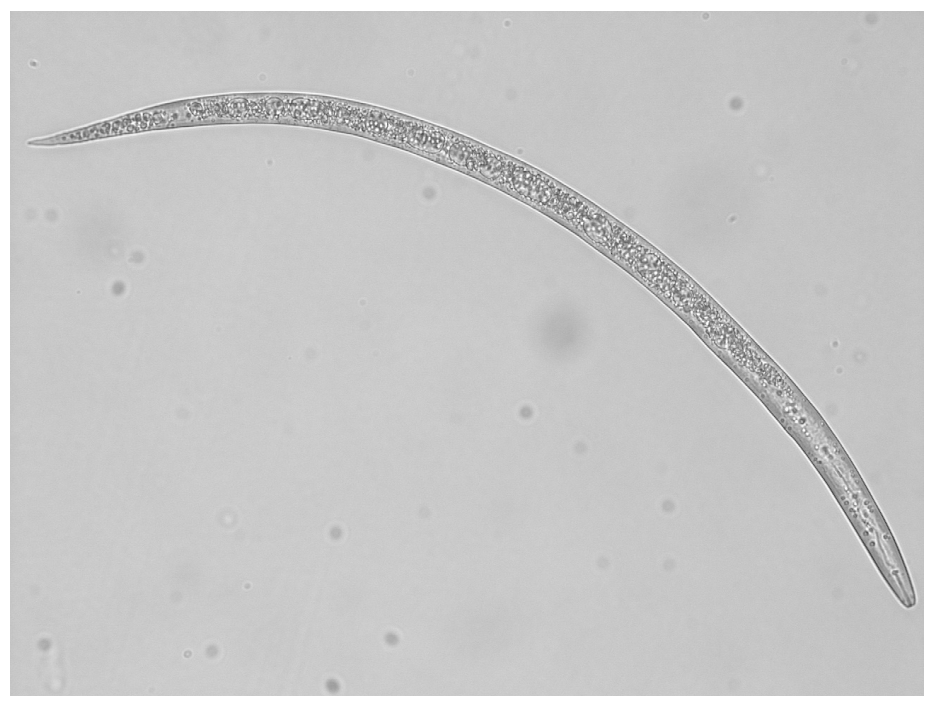

Figure 3. Second-stage juvenile (J2) root-knot nematode under high magnification. This is the stage that emerges from eggs and enters the root to establish a feeding site.

Credits: Zane Grabau, UF/IFAS

\section{Diagnostic and Advisory Services}

Determining what nematodes are present in a field and at what densities is helpful for developing a plan for managing nematodes. This can be accomplished by submitting soil, root, or pod samples to a professional nematology diagnostic lab, such as the UF/IFAS Nematode Assay Laboratory. These samples may be submitted to aid with the diagnosis of disease problems or for advisory service to predict whether or not a potential nematode problem may exist for a future crop. This information allows growers the opportunity to implement management practices to reduce the damage that nematodes may cause. 


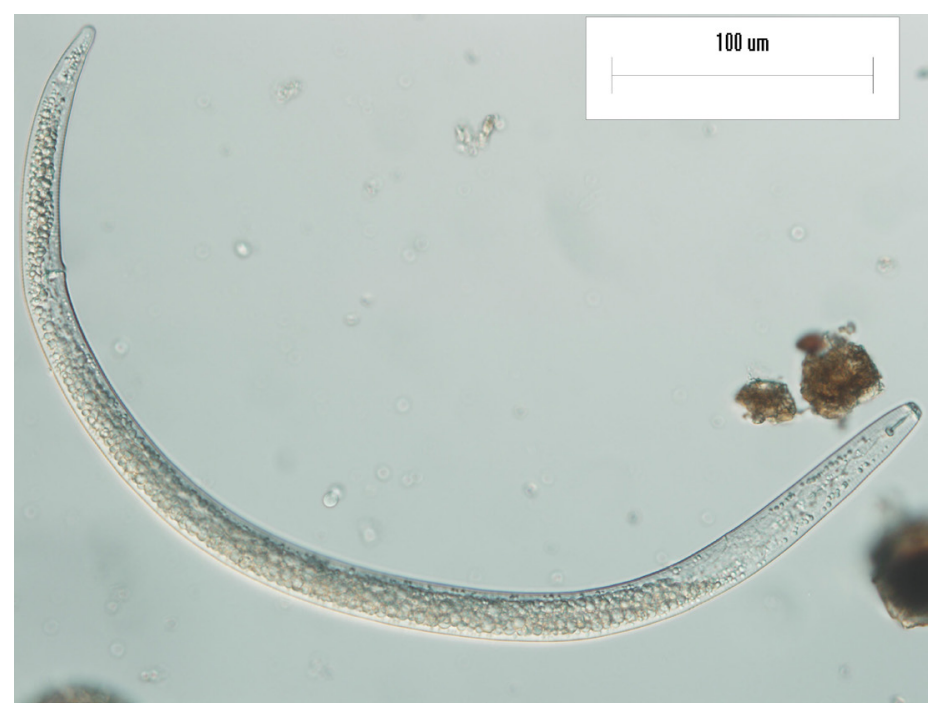

Figure 4. Female lesion nematode under high magnification. Credits: Zane Grabau, UF/IFAS

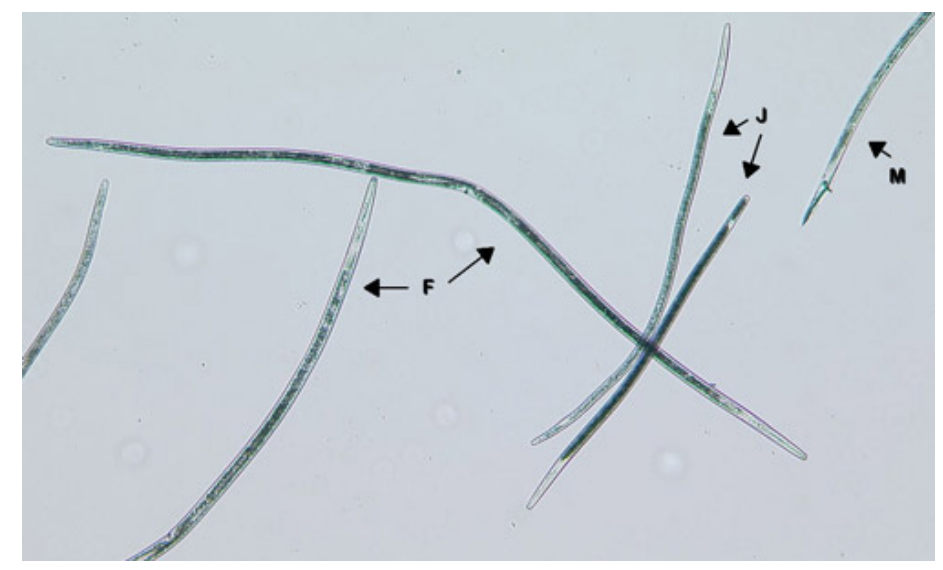

Figure 5. Sting nematode females (F), males (M), and juveniles (J) under high magnification.

Credits: William Crow, UF/IFAS

Detailed information about sampling for nematodes can be found in the EDIS Publication ENY-027, "Sampling Instructions for Nematode Assays." When submitting samples for nematode diagnosis, either soil or soil-and-plant-root samples should be included. Always collect soil because ectoparasitic nematodes can only be recovered from the soil, and at least one stage of all endoparasites can be found in soil. It can be useful to collect plant roots in addition to soil when diagnosing crop damage. If the problem is caused by an endoparasitic nematode, then some nematodes will be found inside the roots.

Soil samples for nematodes should be taken to about 12 inches deep. If plants or remnants of plants are still in the field, soil samples should be taken within a few inches of plant stems and should intersect plant roots if possible. Because nematode densities vary considerably across a field, about 20 soil cores of about an inch in diameter should be taken from an area of 10 acres or less. Thoroughly mix cores collected within a single area, and submit a 1-pint portion of this mixture for analysis. For larger areas, take multiple, separate samples, making sure to properly label them. Do not take samples when soil is excessively wet or dry. Store soil samples in closed plastic bags to protect them from drying and keep them cool, but not frozen, until shipment. Do not add water. When digging root samples, be sure to retain the soil surrounding the roots to slow decay by microbes. The collection and storage process for root samples is the same as the process for soil samples. If you intend to diagnose a problem with the current crop, it may be useful to collect separate samples from the symptomatic area and a healthy area for comparison.

While samples can be taken at any time, nematode populations fluctuate throughout the year, so timing can be important. In most cases, nematode population densities peak around harvest while plant roots are still in the ground, so that is an ideal time to take routine or predictive samples. When diagnosing crop damage, take samples as soon as you see damage and then again around harvest. For questions about sampling for nematodes, contact your local Extension agent, personnel of the Nematode Assay Lab, or the authors of this paper.

\section{Foliar Symptoms}

While diagnosis by a professional is generally needed to confirm the cause of crop damage, there are a number of symptoms that can alert growers to nematode problems. Foliar symptoms of nematode infection are often similar to those caused by nutrient deficiency or diseases and include stunted, yellowed plants. These symptoms often occur in oval or irregular patches in the field corresponding to areas of greater plant-parasitic nematode densities (Figures 6,7 , and 8 ). The size of the areas damaged will generally increase over time and will often correspond to uneven environmental conditions, such as soil type. Plants infected with root-knot nematodes may also wilt more than healthy plants during hot, dry conditions-particularly late in the season. This symptom is most noticeable during the heat of the day, and plants recover later in the day as the air temperature cools. Sting nematode infection can cause severe stunting, leading to reduced plant stands. These are symptoms that tend to appear early in the crop season.

\section{Below-Ground Signs and Symptoms}

Stunted root systems and reduced yield are common, generalized symptoms of plant-parasitic nematode infection. Specific below-ground symptoms vary by nematode. 


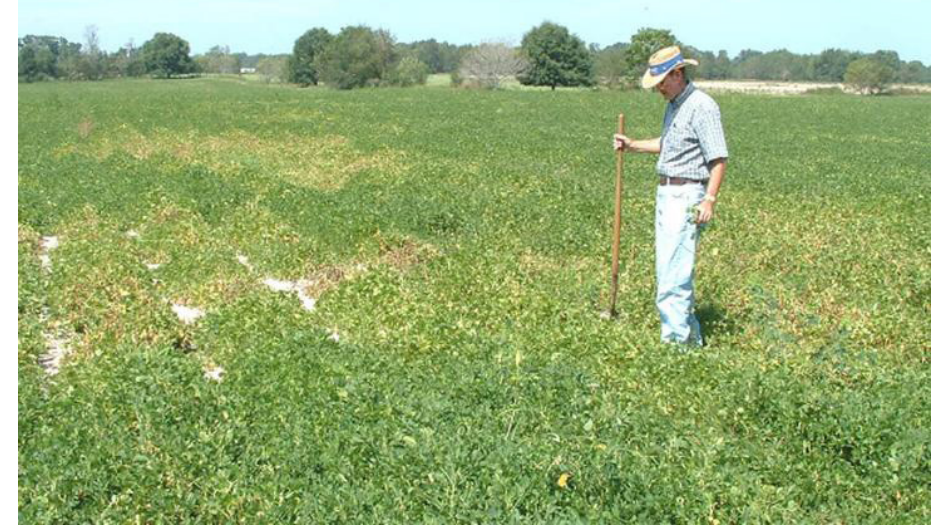

Figure 6. Patches of stunted, dying, and yellowing (chlorotic) peanut plants due to nematode damage.

Credits: Jimmy Rich, UF/IFAS

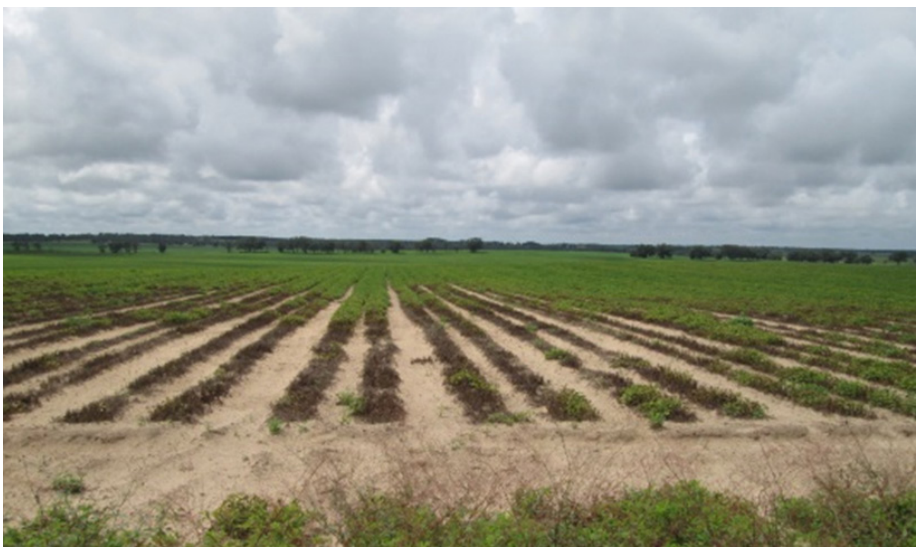

Figure 7. Commercial field with dead peanut plants due to severe root-knot nematode infestation.

Credits: Weimin Yuan, UF/IFAS

Root-knot nematode infection is characterized by irregular swellings, called galls, on the pods, roots, or pegs (Figures 9 and 10). These galls are caused by an increase in the size and number of cells triggered by root-knot nematode feeding. Galls contain one or more sedentary adult female root-knot nematodes. These nematodes are contained in the roots and are small, about $1 \mathrm{~mm}$ in diameter, so it is difficult to view them in the field. However, with some practice, or the aid of a nematologist, it is possible to excise these pearly white females from the roots and see them-a hand lens will make the examination easier. Gall size will vary based on the severity of the infection; galls may coalesce over portions of the pegs, pods, and roots. The amount of galling is dependent on the densities of nematodes and timing of the infection.

Take care to distinguish galls on the root from nitrogenfixing nodules that cover much of the roots (Figure 11). Nitrogen-fixing nodules are an important part of plant health and are spherical attachments that are easily removed from roots. These nodules often have pink interiors

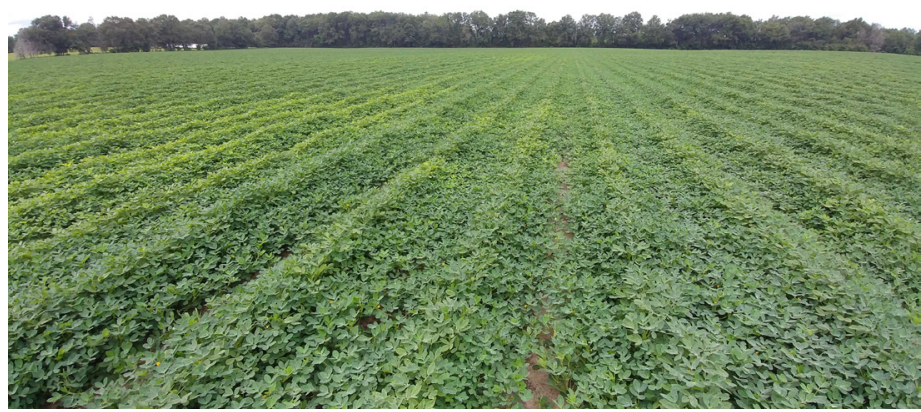

Figure 8. A commercial peanut field in early August with patchy chlorosis (yellowing) due to heavy root-knot nematode infestation. Credits: Zane Grabau, UF/IFAS

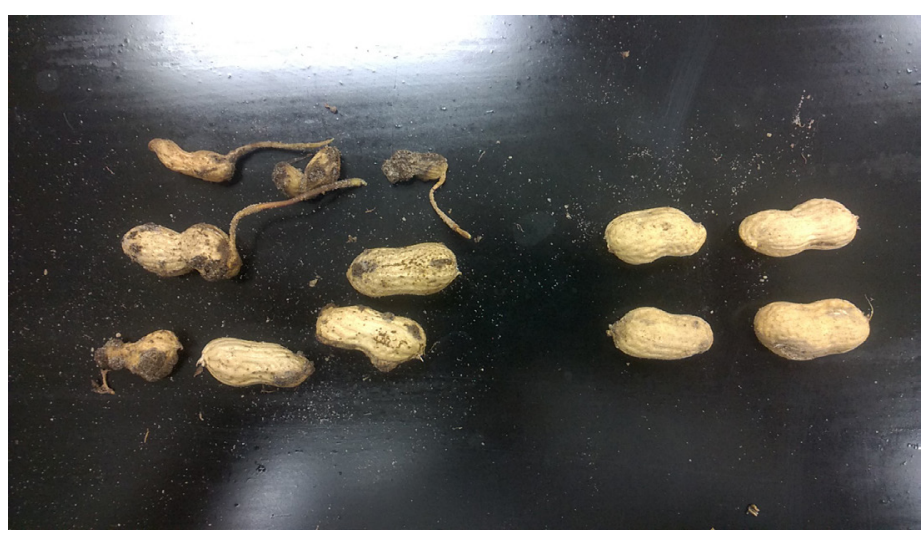

Figure 9. Root-knot nematode causes irregularly shaped growths (galls) on peanut pods (left) while noninfested pods are free of galls (right).

Credits: Zane Grabau, UF/IFAS

when cut in half due to the present of $\mathrm{N}$-fixing bacteria. Galls are irregular swellings of the root itself and cannot be detached without destroying the integrity of the root. Galled roots may show different degrees of root rot because they are favorite sites for secondary infection by plant pathogens. Female root-knot nematodes exude gelatinous egg masses, sac-shaped structures containing hundreds of nematode eggs, either inside the root or on the root surface. These brown egg masses are very small, about $1 \mathrm{~mm}$, which makes them difficult to see, particularly if roots are not washed free of soil debris. Because egg masses are sticky, soil debris clings to the root surfaces (Figure 12).

Lesion nematode damage is most easily visible on pegs and pods where small, irregular shaped, brown lesions occur. Lesion nematodes migrate within the peg and pod tissue in a wandering motion. This motion pattern leaves distinct trails that distinguish nematode lesions from the more oval lesions caused by pod rot organisms. (Figure 13). At higher densities, or as the infection progresses, lesions may darken and coalesce, and often there is an increased incidence of root or pod rot. Heavily infected pegs are weakened, often resulting in pods being dislodged during harvest. Sting nematodes can stunt or stop root growth in part or, in 


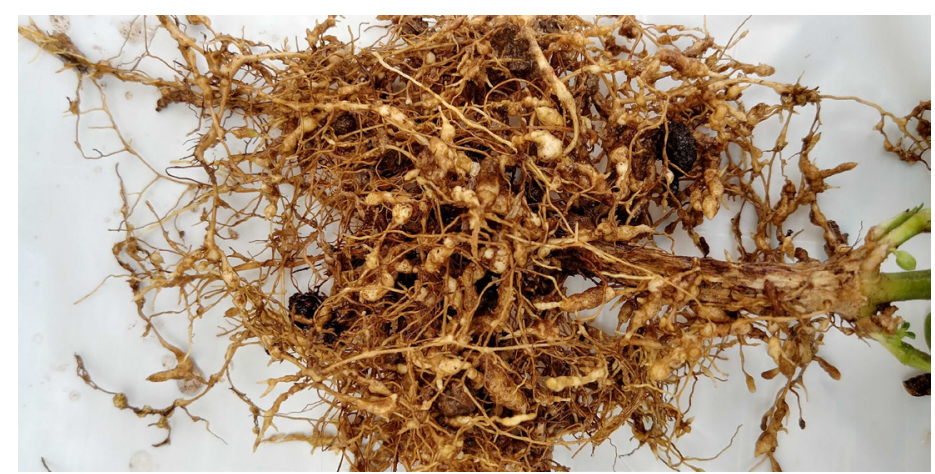

Figure 10. A peanut root system with heavy galling (irregular swellings of the root) due to infection by root-knot nematodes. Credits: Zane Grabau, UF/IFAS

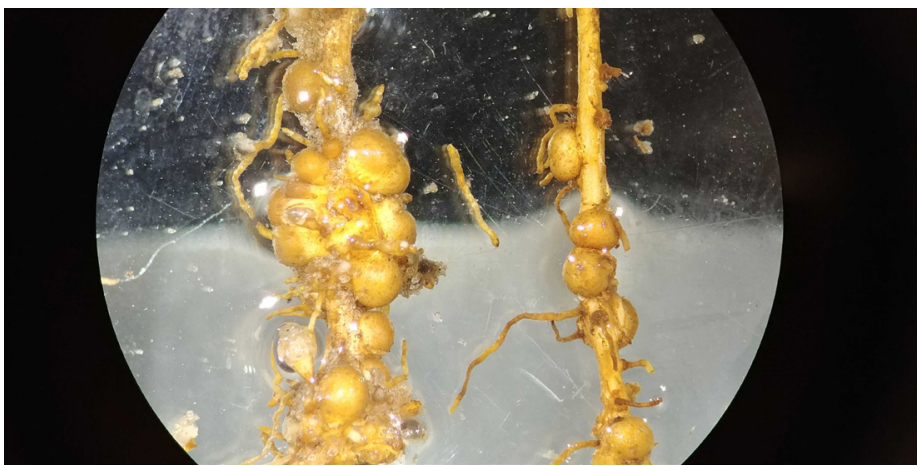

Figure 11. Healthy peanut root (right) compared to a peanut root infected with root-knot nematode. Both roots have spherical nitrogen-fixing nodules attached to the sides of the root. The infected root exhibits galling, irregular swelling of the root itself, as a result of root-knot nematode infection.

Credits: Zane Grabau, UF/IFAS

extreme cases, all of the root system. Infection on pegs and pods is characterized by singular, pin-point-sized brown lesions (Figure 14). Foliar symptoms of sting nematode infection include stunted plants and reduced stand due to plant death (Figure 15).

\section{Management}

Once plant-parasitic nematodes infest a field, it is not possible to eradicate them. Rather, the goals are to minimize crop damage and to keep nematode densities low, ideally at a level where no crop loss occurs. The best way to manage a nematode problem is to use a combination of the most effective and economical practices for the given production situation based on nematode infestation levels, other pest and pathogen problems, available equipment, economics, and other considerations.

\section{Exclusion}

Exclusion is taking steps to stop or slow the spread of one or more plant-parasitic nematodes from infested to non-infested fields. Nematodes do not actively migrate from field to field; rather, they are transported in infested

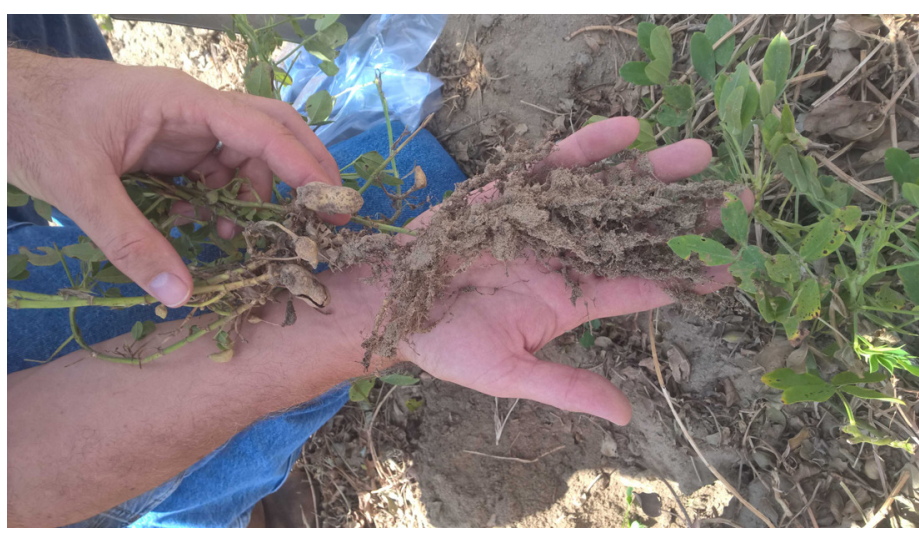

Figure 12. Soil clings to the surface of peanut roots infected by rootknot nematode due to the sticky root-knot nematode egg masses produced at the root surface.

Credits: Zane Grabau, UF/IFAS

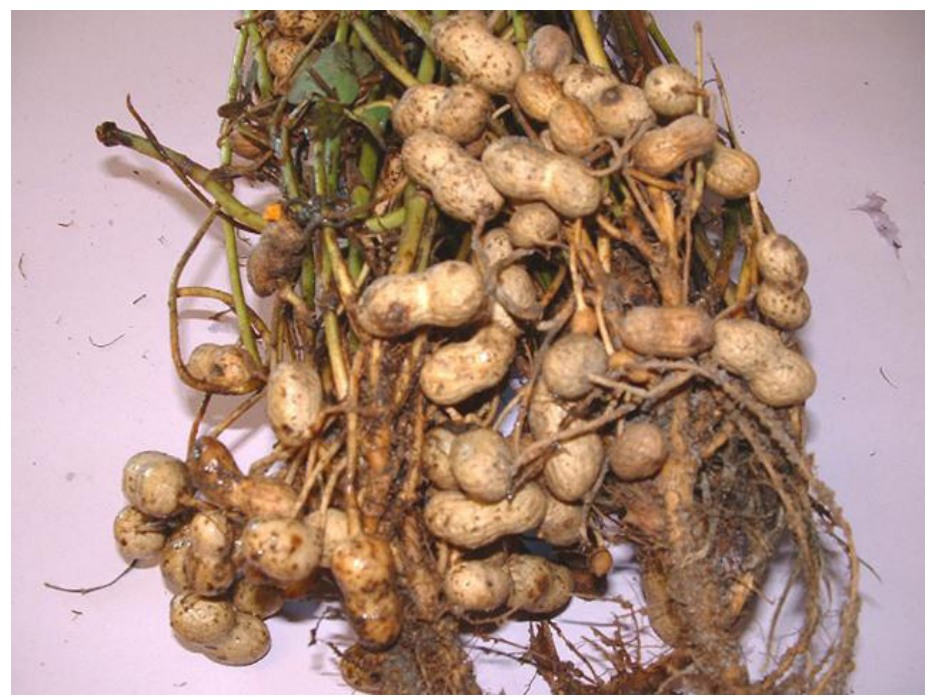

Figure 13. Circular, light brown lesions of necrotic tissue on pods from lesion nematode infestation.

Credits: Jimmy Rich, UF/IFAS

soil, water, or plants. Wind, rain, and animals move these materials, but they are most readily carried on farming equipment. Besides avoiding intentionally moving soil or plant material, cleaning these materials from field equipment can slow nematode movement. This is particularly important when working both infested and non-infested areas. Nematodes can also be brought in on infected planting material. Nematodes do not infest peanut seed but can be found in soil, roots, or pods if these materials are mixed with peanut seed.

\section{Crop Rotation}

Producers can use crop rotation to reduce nematode densities by growing a crop that supports little to no reproduction of the particular nematode (poor or non-host crop). In the absence of a host on which to reproduce, the nematode population decreases as a portion of the nematodes die through natural processes. As an aid for choosing 


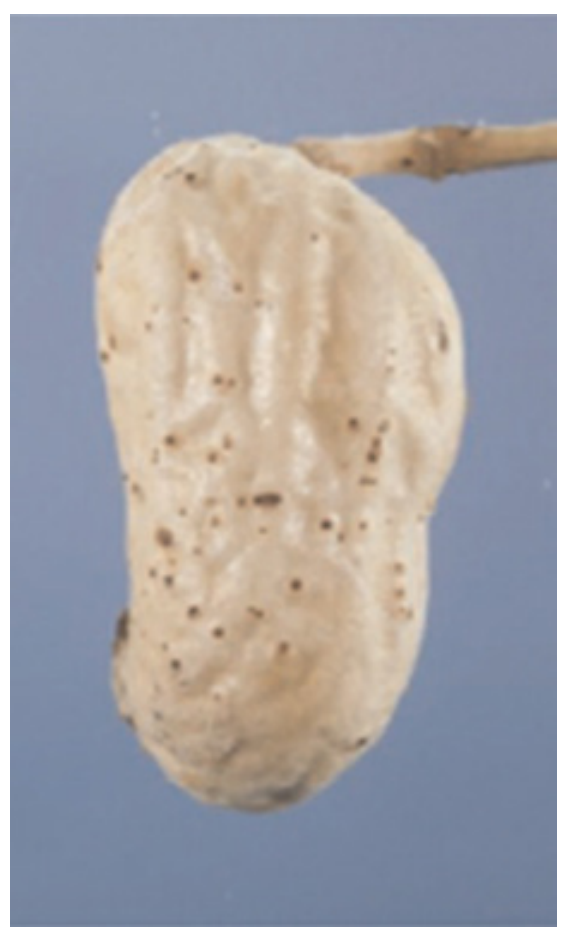

Figure 14. Pin-prick sized, brown lesions of necrotic tissue caused by sting nematode.

Credits: Kanan Kutsuwa, UF/IFAS

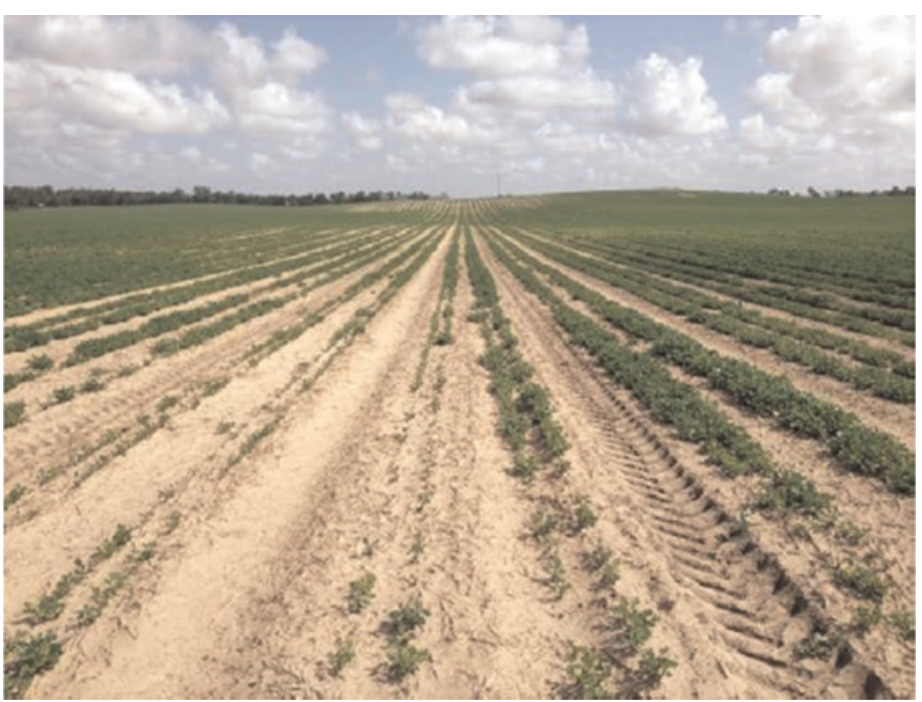

Figure 15. Stunted plants and reduced stand due to plant death caused by sting nematode.

Credits: Kanan Kutsuwa, UF/IFAS

rotation crops to manage nematodes, the host status to plant-parasitic nematodes of peanut is listed in Table 1 for selected crops. Grasses, such as bahiagrass, bermudagrass, millet, and sorghum are effective rotation crops for the peanut and Javanese root-knot nematodes. Most corn cultivars are probably hosts of these nematodes-even if galling is not evident-but may be better than continuous peanut for managing these nematodes. Cotton and peanut are good rotation partners for managing root-knot nematodes because the root-knot nematodes that infect peanut do not infect cotton, whereas the cotton or southern root-knot nematode (Meloidogyne incognita) does not infect peanut.

Both lesion and sting nematodes have wide host ranges, so it is difficult to find a crop rotation that helps manage these nematodes based on current knowledge. Watermelon may be an effective rotation crop for managing sting nematode, but may not be a practical fit for all agronomic crop producers. Grasses are especially good hosts for sting and lesion nematodes and should be avoided where these nematodes are a concern. Weed management is an important supplement to crop rotation because plant-parasitic nematode population densities can be maintained or increased on weedy hosts, including volunteer peanut, hairy indigo, morning glory, Alyce clover, and citron, all of which are commonly found in peanut fields in Florida.

\section{Fallow and Cover Cropping}

Offseason periods when a cash crop is not grown should also be considered as part of a crop rotation strategy. These periods are opportunities to reduce or exacerbate nematode problems. Fallowing fields in the offseason can help reduce nematode densities, but only if weedy nematode hosts, including volunteer peanut, are controlled. However, erosion can be a major problem when fallowing fields, particularly on sandy soils.

If you grow a cover crop, choose a non-host for the nematodes present in your field. Table 1 includes a summary of the host status of selected cover crops for root-knot and sting nematodes. Most common winter grain cover crops are poor hosts of root-knot nematodes, although this varies by cultivar and nematode species, and some are good hosts of sting nematode. Additionally, some cover crops, such as Brassicas (radish, mustards, etc.), may have nematicidal properties, directly reducing densities of nematodes, although not typically to the same degree as chemical products.

Even cover crops with nematicidal properties are hosts of certain nematodes, such as most Brassicas for root-knot nematodes. Nematode reproduction on a good host will generally counteract any nematicidal effects, so host status should be considered for these cover crops as well. For further information on cover cropping for nematode management, see these UF/IFAS publications on cover crops for root-knot nematodes (http://edis.ifas.ufl.edu/ in892), sunn hemp (http://edis.ifas.ufl.edu/ng043), cowpea (http://edis.ifas.ufl.edu/in516), and marigolds (http://edis. ifas.ufl.edu/ng045). 


\section{Resistant Cultivars}

Some peanut cultivars with a high level of resistance to root-knot nematodes are available. These resistant cultivars prevent or reduce reproduction by root-knot nematodes but are not known to reduce reproduction by lesion, sting, or ring nematodes. Three runner-type peanut cultivars, Tifguard, TifNV-High O/L and Georgia-14N, are highly resistant to root-knot nematodes. These cultivars are also resistant to Tomato spotted wilt virus (TSWV). TifNV and Georgia-14N are high-oleic varieties. All three cultivars are reported to share two RKN resistance genes, which results in a highly effective source of resistance. However, growing them repeatedly in a monoculture is not advisable because this practice may result in the selection of resistancebreaking within the root-knot nematode populations. There is no information currently available on how long it would take resistance-breaking populations to build up, but including non-hosts of the peanut and Javanese root-knot nematodes and RKN-susceptible peanut cultivars in a crop rotation system may slow their development.

When employing resistant cultivars for nematode management, it is important to obtain seed from a reliable source that ensures a high level of quality control, such as a certified seed source. For resistance to be maintained, the seed source must ensure a high level of purity.

\section{Nematicides and Other Commercial Products}

Nematicides are chemical products intended to reduce nematode densities. To protect workers, consumers, and the environment, nematicides must be used as specified on the label and only on those crops listed on the label. Nematicides labeled for peanut production include fumigants-broad-spectrum pesticides that move through soil as a gas-or nonfumigants-liquid products with a narrow spectrum of activity. Ideally, nematicides improve the chances for a successful crop by reducing crop damage from nematodes. Before applying nematicides, growers should consider whether application is likely to provide an economic return at the given infestation level. If a previous crop of peanut was severely damaged, that is a strong indication that a soil fumigant may need to be applied if peanut is to be grown again in the damaged field.

The fumigant 1,3-dichloropropene (Telone II) is available for use on peanut by a certified applicator and can be effective for managing nematode problems. This product is applied as a liquid that volatilizes once in soil, moving through the soil profile. 1,3-D is often applied in the row at less than the full label rate to reduce input costs and provide an economic return. To ensure maximum efficacy, it is important to apply $1,3-\mathrm{D}$ in a manner that maximizes fumigant movement through the soil profile and thus improves chances for contact with nematodes. This means injecting the fumigant to at least a 10- to 12-inch depth using a shank or other equipment, then sealing and compacting the soil. Information on application methods and nematicides labeled for peanut is provided in Table 2 .

Metam sodium and metam potassium are broad-spectrum products that are also labeled for nematode management in peanut. They are most commonly used at reduced label rates to aid with suppression of soilborne fungal diseases of peanut. At low rates, they are not very effective for nematode management. They are formulated and applied as liquids, but they do not readily volatilize once in soil, therefore they depend on water to transport them through the upper soil. They must be sprayed over the soil surface and incorporated with a tillage instrument or injected with closely spaced chisels (e.g., 5 to 7 inches apart).

Three nonfumigant nematicides, fluopyram, aldicarb, and oxamyl are currently registered and labeled for Florida peanut production. Oxamyl (Vydate C-LV and Return XL) is liquid spray that can be applied in soil at planting and as a foliar spray after peanut emergence. Fluopyram is a new active ingredient introduced recently and is combined with the insecticide imidacloprid in the current product Velum Total. For nematode control in peanut production, fluopyram would be applied as an in-furrow spray. It has received only limited testing in UF/IFAS trials. Aldicarb is the active ingredient in AgLogic, a granular nematicide/ insecticide that can be applied in-furrow at planting and side-dressed just before pegging. Aldicarb may be familiar to growers as the active ingredient in Temik, a discontinued pesticide.

A commercial product (Melocon WG) that contains live spores of the fungus Purpureocillium lilacinum (formerly named Paecilomyces lilacinus) is also labeled for nematodes on peanut, although previous testing suggests it is not as effective as chemical nematicides. The product can be used in organic production and should be applied around planting and again before pegging (Table 2). Melocon WG is formulated as a solid and must be stored in a cool location $\left(70^{\circ} \mathrm{F}\right.$ or less), not mixed with or exposed to other chemicals, and applied with at least 20 gallons of water per acre because the product contains live organisms. 


\section{Other Practices}

Practices that promote plant health may help plants better tolerate nematode infection even if they do not reduce nematode populations. This includes practices such as maintaining soil fertility and tilth, providing adequate water, and managing insects and plant pathogens. Good knowledge of environmental and biological properties of your soil can also be a tool in nematode management. As mentioned above, soil type and texture influence where nematode damage is likely to occur.

Some soils keep plant-parasitic nematode densities low despite a susceptible crop. This suppression often develops gradually over a period of time. Practical and tested methods for developing suppressive soils have not been established, but natural predators and pests of nematodes are one cause of nematode-suppressive soils. Recognizing suppressive soils by monitoring nematode densities and cropping history can help cut costs by eliminating unnecessary management practices.

\section{Selected References}

Branch, W. D., and T. B. Brenneman. 2015. "Registration of 'Georgia-14N' peanut." Journal of Plant Registrations 9:159-161.

Burris, E., D. Burns, K. S. McCarter, C. Overstreet, M. Wolcott, and E. Clawson. 2010. "Evaluation of the effects of Telone II (fumigation) on nitrogen management and yield in Louisiana Delta cotton." Precision Agriculture 11:239-257.

Chen, Z., and D. Dickson. 1998. "Review of Pasteuria penetrans: Biology, ecology, and biological control potential." Journal of Nematology 30:313-340.

Johnson, A. W., C. C. Dowler, and Z. A. Handoo. 2000. "Population dynamics of Meloidogyne incognita, M. arenaria, and other nematodes and crop yields in rotations of cotton, peanut, and wheat under minimum tillage." Journal of Nematology 32:52-61.

Koenning, S., C. Overstreet, J. Noling, P. Donald, J. Becker, and B. Fortnum. 1999. "Survey of crop losses in response to phytoparasitic nematodes in the United States for 1994." Journal of Nematology 31:587-618.

Kokalis-Burelle, N., D. M. Porter, R. Rodriguez-Kabana, D. H. Smith, and P. Subrahmanyam (eds.) 1997. Compendium of peanut diseases. Second ed. The American Phytopathological Society, Saint Paul, MN.
Kutsuwa, K., D. W. Dickson, J. A. Brito, A. Jeyaprakash and A. Drew. 2015. "Belonolaimus longicaudatus: An emerging pathogen of peanut in Florida." Journal of Nematology 47:87-96.

Moore, S. R., and K. S. Lawrence. 2012. "Rotylenchulus reniformis in cotton: Current methods of management and the future of site-specific management." Nematropica 42:227-236.

Oka, Y. 2010. "Mechanisms of nematode suppression by organic soil amendments-A review." Applied Soil Ecology 44:101-115.

Thomas, S., J. Schroeder, and L. Murray. 2005. “The role of weeds in nematode management." Weed Science 53:923-928.

Wang, K., R. McSorley, R. N. Gallaher, and N. KokalisBurelle. 2008. "Cover crops and organic mulches for nematode, weed and plant health management." Nematology 10:231-242. 
Table 1. Host status of selected cash and cover crops for management of specific plant-parasitic nematodes of peanut. ${ }^{1}$

\begin{tabular}{|c|c|c|c|}
\hline Crop & Peanut root-knot nematode ${ }^{2}$ & Javanese root-knot nematode & Sting nematode ${ }^{2}$ \\
\hline \multicolumn{4}{|c|}{ Agronomic or forage crops } \\
\hline Bahiagrass & Poor/non-host & Unknown ${ }^{3}$ & Good host \\
\hline Carinata & Good host & Good host & Unknown \\
\hline Corn & Varies by cultivar & Good host & Good host \\
\hline Cotton & Poor/non-host & Poor/non-host & Good host \\
\hline Millet & Varies by cultivar & Varies by cultivar & Good host \\
\hline Potato & Good host & Varies by cultivar & Good host \\
\hline Sesame & Varies by cultivar & Good host & Unknown \\
\hline Sorghum & Poor/non-host & Varies by cultivar & Good host \\
\hline Soybean & Varies by cultivar ${ }^{4}$ & Varies by cultivar ${ }^{4}$ & Good host \\
\hline Sugarcane & Unknown & Good host & Good host \\
\hline Tobacco & Good host & Good host & Poor/non-host \\
\hline \multicolumn{4}{|c|}{ Fruit or vegetable crops } \\
\hline Field pea & Unknown ${ }^{5}$ & Good host & Good host \\
\hline Melon (specialty) & Varies by cultivar ${ }^{4}$ & Varies by cultivar ${ }^{4}$ & Good host \\
\hline Snap bean & Good host & Good host & Good host \\
\hline Tomato & Varies by cultivar ${ }^{4}$ & Good host & Good host \\
\hline Watermelon & Good host & Good host & Poor or non-host \\
\hline \multicolumn{4}{|l|}{ Selected cover crops } \\
\hline Sudan grass & Poor/non-host & Poor/non-host & Good host \\
\hline Winter oats & Poor/non-host & Varies by cultivar & Good host \\
\hline Winter rye & Varies by cultivar & Unknown ${ }^{3}$ & Good host \\
\hline Winter wheat & Varies by cultivar & Varies by cultivar & Good host \\
\hline \multicolumn{4}{|c|}{$\begin{array}{l}{ }^{1} \text { Information is based on observations and literature at the time of publication. Relationships may differ for specific nematode populations a } \\
\text { crop cultivars. } \\
{ }^{2} \text { Host range of peanut root-knot nematode varies by race or population. There is evidence that physiological or geographic races of sting } \\
\text { nematode also exist, but these are not well-established. } \\
{ }^{3} \text { Bahiagrass and winter rye are poor or non-hosts of most root-knot nematode species but have not been tested against the Javanese root- } \\
\text { knot nematode } \\
{ }^{4} \text { This crop is a good host of the specified nematode, but some resistant cultivars or rootstocks are available. } \\
{ }^{5} \text { Legumes, a group that includes field pea, are generally good hosts of peanut root-knot nematode, but field pea has not been tested. }\end{array}$} \\
\hline
\end{tabular}




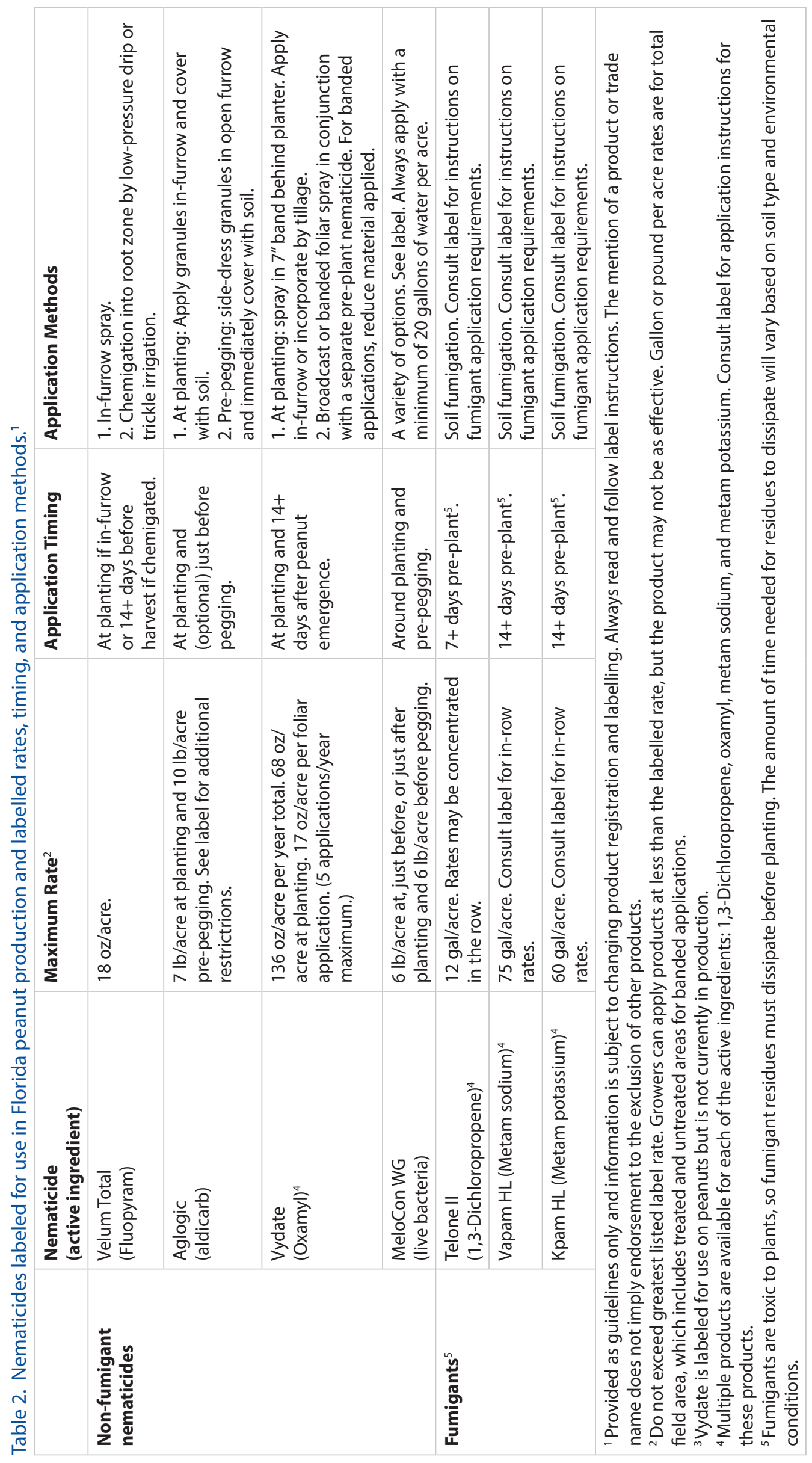

